Vol. 5, No. 2, 2020

\title{
THEORETICAL AND PRACTICAL ASPECTS OF THE EFFICIENCY OF APPLICATION OF MINERAL FERTILIZERS ENCAPSULATED WITH POLYETHYLENE TEREPHTHALATE
}

\author{
Serhiy Synelnikov ${ }^{1}$, Myroslav Malovanyy ${ }^{1}$, Oleh Nahurskyy ${ }^{2}$, Liubov Luchyt ${ }^{3}$, \\ Kateryna Petrushka ${ }^{1}$, Ivan Tymchuk ${ }^{1}$, Oleh Stokaliuk ${ }^{4}$ \\ ${ }^{1}$ Department of Ecology and Sustainable Environmental Management \\ ${ }^{2}$ Department of Civil Safety, \\ Institute of Sustainable Development, \\ ${ }^{3}$ Department of Foreign Languages \\ Institute of Humanities and Social Sciences, Development, \\ Lviv Polytechnic National University, \\ 12, S. Bandery Str., Lviv, 79013, Ukraine, \\ ${ }^{4}$ Institute of Civil Protection, \\ Lviv State University of Life Safety, \\ 35, Kleparivska Str., Lviv, 79007, Ukraine, \\ myroslav.mal@gmail.com,o_nagurskyy@ukr.net
}

https://doi.org/10.23939/ep2020.02.095

Received: 13.04 .2020

(C) Synelnikov S., Malovanyy M., Nahurskyy O., Luchyt L., Petrushka K., Tymchuk I., Stokaliuk O., 2020

\begin{abstract}
The environmental impact of residual mineral fertilizers not utilized by plants is analyzed. It is shown that this negative effect extends to all elements of the environment: soil, atmosphere, hydrosphere. The perspective of the application of encapsulated mineral fertilizers that allow prolonged release of plant nutrients is outlined. The appliccation of modified polyethylene terephthalate (PETF) as a capsule-forming material for encapsulated mineral fertilizers is proposed. PET modification and fertilizer encapsulation technologies have been tested. The dynamics of the release of nutrients from fertilizers encapsulated by PET has been studied. The kinetics of watercress salad growth with the use of granular and encapsulated fertilizers has been investigated.
\end{abstract}

Key words: granulated mineral fertilizers, encapsulated mineral fertilizers, environment, nutrients, polyethylene terephthalate, release.

\section{Introduction}

There is a rapid increase in agricultural production in all countries of the world, increasing the cost of food and interest in the development of agricultural production [1, 2]. The rapid increase in agricultural production is accompanied by environmental pollution with pesticides and other agrochemical compounds, an increase in the material production of these compounds, a decrease in the share of organic fertilizers that renew the organic matter in soils [3, 4], and leads to environmental pollution. Environmental pollution with mineral fertilizers occurs at all stages of their life cycle (production, transportation, and application).

Only a part of fertilizers is absorbed by the root system of crops within the following limits: nitrogen compounds 50-60 \%; potassium 50-60\%; phosphorus 10-25\%; [5]. The fertilizers that are not digested by plants lead to soil stabilization, and contamination of surface water bodies. Undissolved fertilizer particles fall into groundwater and surface water. Most mineral fertilizers are salts that dissolve rapidly in water during a significant amount of rainfall and have a tendency to migrate to the soil, especially during their application and during the growing season $[6,7]$.

The decrease in the yield and quality of the crop is due to the lack of mineral fertilizers $[8,9]$. The environment is polluted by dissolved fertilizers that are washed out of the soil during precipitation. As a result, the concentration of nitrates in drinking water increases as well as the scale of the process of eutrophication of 
reservoirs, which causes the flowering of water. Lakes, ponds, technical water bodies, rivers, and reservoirs are sensitive to numerous water-soluble nitrogenous, phosphorous, and potassium compounds. There is an increase in the level of populations of blue-green cyanobacteria, which in the process of growth and development produce toxins that belong to highly toxic natural compounds. They alter the metabolism of proteins and carbohydrates and have a negative impact on the human central nervous system $[10,11]$.

Contamination of surface water bodies is due to the increase in the concentration of nitrites and nitrates in the water caused by fertilizer application. Highly carcinogenic nitro-replacements arise from the interaction of nitrites and nitrates with biologically active amines, or nitrogen-containing substances, which are present in water bodies and are formed due to the decomposition of algae $[12,13]$.

Mineral fertilizers are dissolved in the soil due to precipitation. In case of insufficient rainfall, mineral fertilizers are dissolved due to groundwater. A lot of fertilizers remain undissolved, and the soil becomes saline. There is a destruction of the ozone layer, the restoration of nitrates to nitrites, gaseous oxides, and molecules of nitrogen. As a result, nitrogen returns to the atmosphere and becomes inaccessible for most organisms.

The utilization rate of the main fertilizer components is reduced due to various reasons. Their efficiency decreases also during the irregular application of fertilizers: phosphorus and potassium - by 15-20\%; complex - by 28-35\%; simple ones - by 35-45\% [14, 15]. Excessive fertilizer application results in reduced fertilizer utilization rates and nutrient losses. Each type of soil needs different types of fertilizers. Fertilizer application provides nutrition to the root system of rotation crops, but it is necessary to ensure that the needs of plants in the nutrients are provided with the costs to maintain soil fertility at allowable costs that prevent water contamination with fertilizer residues.

Environmental problems are caused by the improper application of fertilizers or by the excessive amount of fertilizer applied. As a result, soil salinization, leaching of nitrate and potassium fertilizers into underground aquifers occur. The losses of nitrogen and other nutrients are increased by the surface application of fertilizers or the drainage of territories. The accumulation of potassium and phosphorus occurs when a large dose of fertilizer is applied in the arable and sub-arable layers of the soil. Chemical compounds penetrate groundwater deeply [16].

Compared to nitrogen fertilizers, contamination with phosphorus fertilizers in natural reservoirs is less. Most phosphorus enters reservoirs from wind and water erosion. Absorption of soil microflora and adsorption by soil colloids are due to phosphate sediments in which phosphorus is fixed by soil and a complex of compounds with humic substances [17]. The rapid removal of biogenic elements into the agro-ecosystem and their subsequent leaching into water horizons is a major problem with horizontal and vertical migration.

In anaerobic conditions, losses of gaseous nitrogen increase because of denitrification during precipitation. With surface fertilizers, migration of soil profiles of fulvic acids and humic acids, calcium and magnesium cations increases. On acidic soils, this process is more active [18]. The application of nitrate, chloride and sulfate fertilizers leads to an increase in the losses of calcium and magnesium, the reason being the inability to retain nitrate and chloride ions in the soil; and when dissolved in water, fertilizers bind to an equivalent amount of cations $\mathrm{Ca}^{2+}, \mathrm{Mg}^{2+}$. Nitrogen and other mineral fertilizers have a different impact on the soil microflora. Most often they prolong the life of microorganisms and microfauna. Organic fertilizers have the greatest impact on the biological activity of the soil.

The reduction of environmental pollution with mineral fertilizers is possible under conditions of controlled dissolution of compounds [20]. The use of prolonged-action fertilizers reduces the likelihood of precipitation of these fertilizers, increases the duration of their action, improves plant nutrition and allows the release of a controlled-speed component. Due to the application of prolonged fertilizers, the soil fertility is increased and the necessary nutrients are provided for the growth and development of plants by the nutrients.

A promising method of releasing nutrients from a fertilizer element into the soil is the coating of mineral fertilizer particles with capsules using polymers (encapsulated mineral fertilizers). It is possible to synthesize mineral fertilizer granules by introducing additives from the same compounds (e.g. polyacrylamide) or substances that can be polymerized [21]. Polymeric capsules covering fertilizer pellets are permeable to aqueous solutions and water. But they prolong the release of nutrient elements into the soil. This slowdown is determined mainly by the thickness and composition of the polymer capsule. When the capsules are impermeable but capable of biodegradation in the soil medium, the contents of the granules are released into the soil medium to the extent of biodegradation. For this variant of release, it is not the intensity of the dissolution of the mineral fertilizer granule that is regulated, but the onset of biodegradation of the capsule [22].

As a result of encapsulation, a new type of mineral fertilizer is created, the rate of the release of plant nutrients from which is prolonged. At the same time, it is possible to improve the basic physical characteristics of the mineral fertilizer [23].

Encapsulated fertilizer is characterized by increased strength, reduced adhesion, and hygroscopicity. This allows us to increase the critical shelf life of the fertilizer, while its quality indicators do not deteriorate. 
This helps to reduce the costs of storage, storage, transportation, and fertilizer application. The uniformity of fertilizer distribution across the application area is improved, which makes it possible to bring them more evenly into the fields using specialized technical means [24].

One of the deterrents to the widespread application of encapsulated fertilizer is its high cost compared to conventional granules, despite its agronomic and environmental appeal. Therefore, the application of polymeric waste as a capsule material in encapsulation of mineral fertilizers will allow, on the one hand, to provide a competitive price and a wider use of encapsulated fertilizer, and, on the other hand, to solve the problem of plastic waste disposal. The possibility of the use of plastic waste to encapsulate mineral fertilizer is due to enormous volumes of this type of waste that is suitable to be used in the capsule material [25].

As a result of the encapsulation of mineral fertilizer with a composition comprising plastic waste, the solubility of the nutrients from the capsule nucleus is reduced, and the duration of action is extended. This is caused by a capsule deposited on the core of the basic fertilizer which creates a diffusion resistance to release the nutrients into the soil environment. Thus, the use of plastic waste in the composition of the capsule reduces the total cost of production of capsule fertilizer and prolongs the disintegration of the capsule during the plant vegetation. This enhances the agronomic use of encapsulated fertilizers and reduces the environmental risk of contamination by the nutrients that are not absorbed by plants. To confirm the effectiveness of such a strategy, it is necessary to analyze the ways of the use of plastic products, the dynamics of accumulation of plastic waste of the type that would be optimal for the use in the composition for the encapsulation of mineral fertilizeri, as well as the existing approaches and technologies for the disposal of this type of plastic. Polymeric materials used as the basis of film-forming compositions must meet two basic conditions:

- provide adequate intensity of release of mineral nutrition components;

- be safe for the environment - after the release of the fertilizer components, the shell material must be neutralized in some way to avoid contamination of the soil environment by polymers.

These conditions could be met by polyethylterephthalate (PETF), provided that it is soluble, which plays a crucial role in creating a film-forming composition and coating the mineral fertilizer granules [26]. For PETF the system of separate collection (used PETF bottles) and recycling (secondary raw materials for production of fiber, PETF bottles, sheets for thermoforming, strapping tape, etc.) is widely developed in Ukraine and other countries of the world. Additional studies are required to modify PET to achieve solubility in organic solvents.

The purpose of the study is a theoretical and practical analysis of the application efficiency of the mineral fertilizers encapsulated with polyethyl ethertolate.

\section{Experimental part}

We investigated the possibility of modification of PETP by the method of implementation of the alcoholysis reaction using diethylene glycol (DEG) as a reagent. The studies were carried out at the laboratory installation shown in Fig. 1.

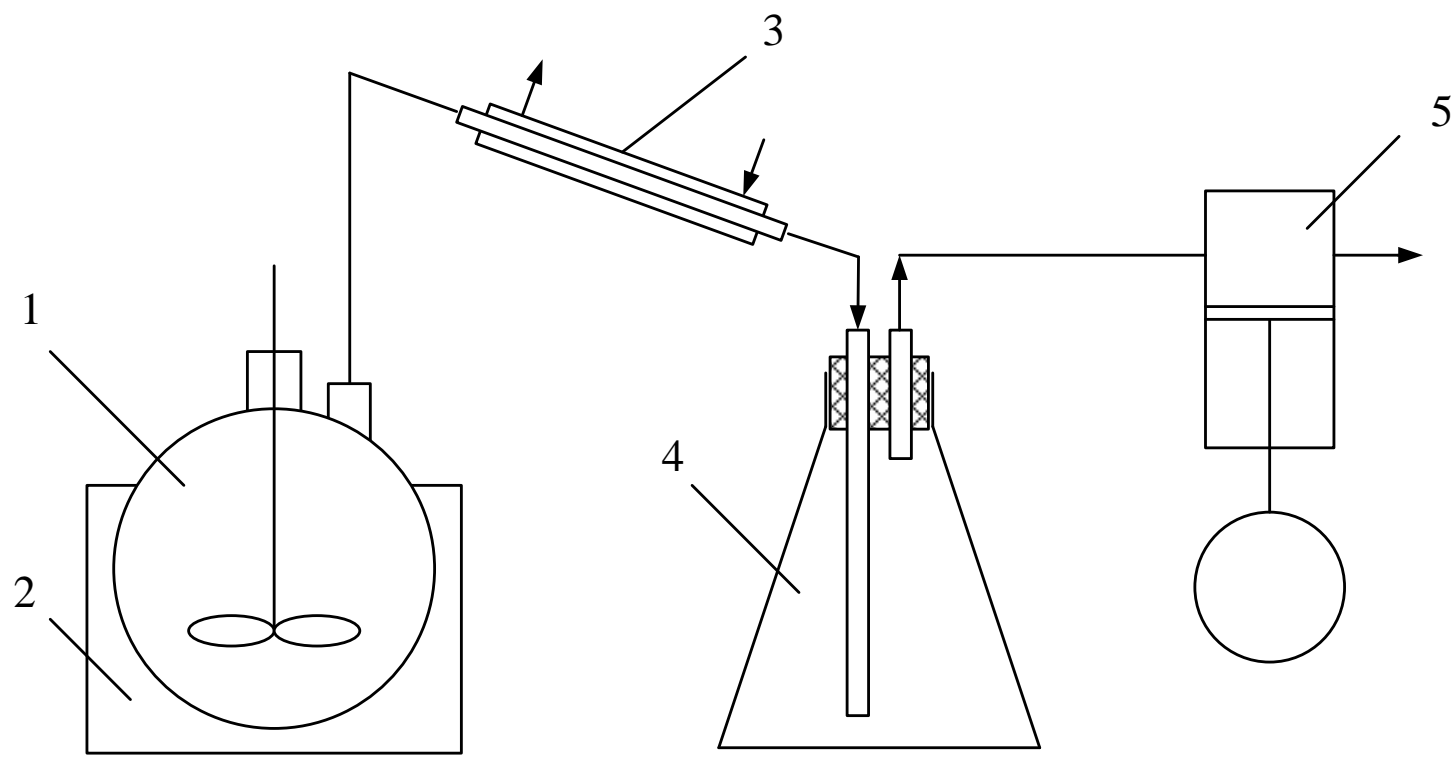

Fig. 1. Installation of PET modification of diethylene glycol:

1 - reactor; 2 - thermostat; 3 - refrigerator; 4 - condensate collector; 5 - vacuum pump 
The reactor (1) was loaded with PET waste in the form of flakes that had undergone primary processing at a specialized plant and diethylene glycol in a molar ratio of PET: DEG 1: 0.5. The contents of the reactor were heated to a temperature of $493 \mathrm{~K}$. Two hours after reaching the required temperature, the vacuum pump (5) was switched on, and ethylene glycol was distilled from the reactor at a residual pressure of $20 \mathrm{kPa}$. The condensate of ethylene glycol obtained in the refrigerator (3) got into the collector (4). The total duration of the process was 3.5 hours. As a result of the interaction, ethylene glycol is displaced with diethylene glycol to produce modified PET soluble in ethyl acetate [1].

The coating of the particles was carried out with a solution - a film-forming agent in the fluidized-bed apparatus of periodic action, the schematic diagram of which is shown in Fig. 2.

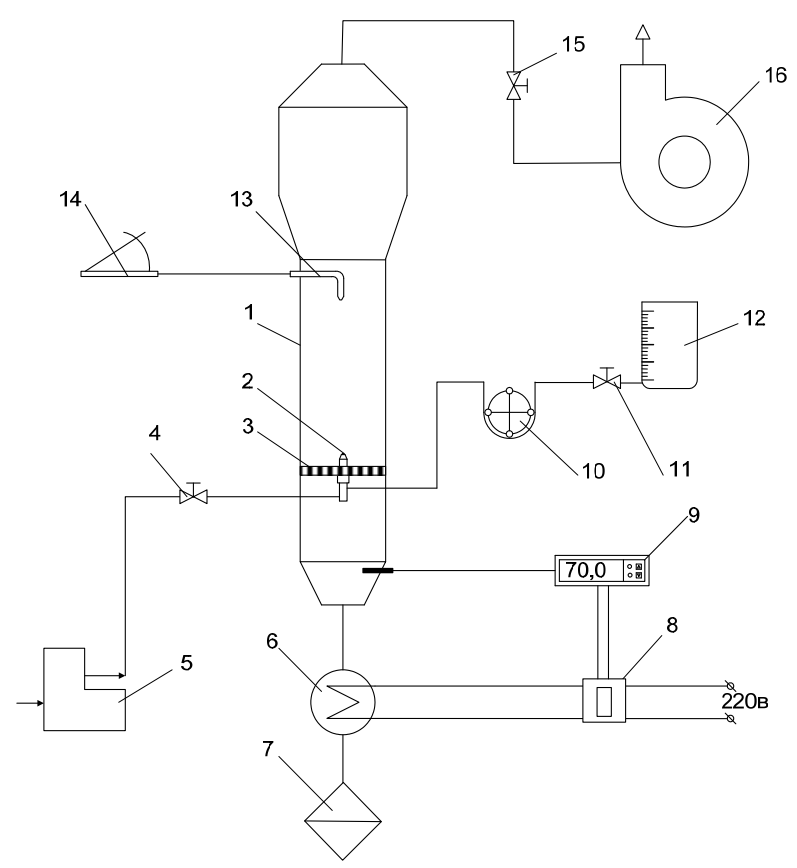

Fig. 2. Scheme of the experimental installation for film coating on solids: 1 - product tank; 2 - nozzle; 3 - gas distribution grid; 5 - compressor; 6 - heater; 7 - air filter; 8 - relay; 9 - regulator-meter RT-0102; 10 - pump dispenser; 12 - measure; 13 - Pitot tube; 14 - difmanometer; 16 - fan; 4, 11, 15 - control valve

The installation consists of a product tank (1) of a cylindrical type, with a gas distribution grate (3) mounted inside it together with a pneumatic nozzle (2). The air to create a "fluidized bed" is heated to the set temperature in the heater (6). Its passage through the installation is provided by a fan (16). The temperature in the installation is fixed and regulated by an electronic controller-meter
RT-0102 9. The flow rate is controlled by an inclined diffuser (14) connected to the Pitot tube 13. The filmforming solution from the measuring instrument (5) is a dispenser pump (6) supplied to the spray nozzle (2). The control of its flow is carried out by the dispenser pump (10). Spraying of the solution is provided with compressed air coming out of compressor 5 .

The encapsulation of solid particles with a waterinsoluble film of different thickness was carried out with a solution of modified PET in ethyl acetate. The process was carried out at an operating temperature of $75^{\circ} \mathrm{C}$ and fluidization numbers of 2.5-3.0. The working chamber of the apparatus was loaded with particles of a total mass of $0.25 \mathrm{~kg}$; the air was supplied at the required speed; the required temperature regime was set, and the film-forming solution was introduced by the pump dispenser to the spray nozzle. The encapsulation process continued until the required thickness was obtained. The general view of the obtained fertilizers is presented in Fig. 3.

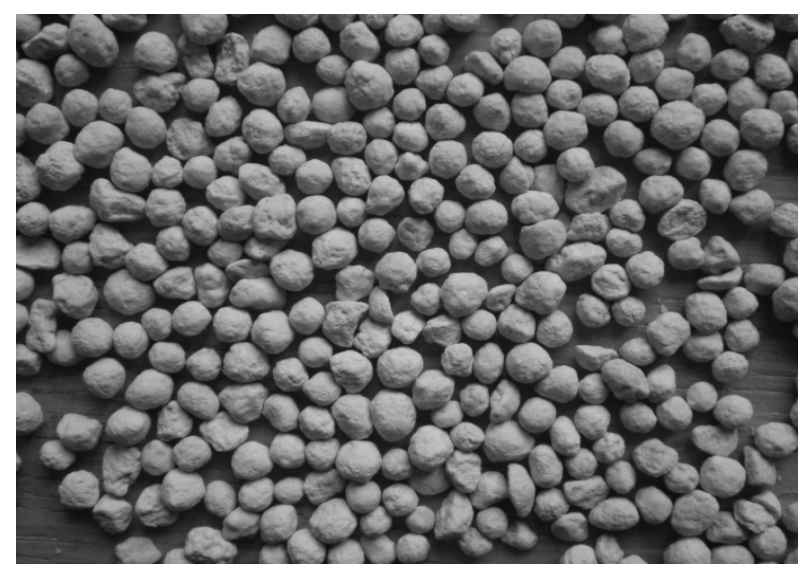

Fig. 3. .Nitroamophoska, encapsulated with a PET-based film

The coating weight was $10 \%$ and $20 \%$ of the fertilizer mass, which corresponds to the average film thickness on the surface of the particles of $5.23 .105 \mathrm{~m}$ and $10.46 .105 \mathrm{~m}$, respectively.

Encapsulation of mineral fertilizers, first of all, is carried out to decrease the solubility of soluble substances. According to European norms for slow-acting encapsulated mineral fertilizers, the criteria for evaluating their efficiency, given in [28], where the kinetics of the process with fixing the release time of 15 and $75 \%$ (wt) of mineral nutrients should be considered.

The experimental studies of the process of the active phase release through the shell were conducted to determine the properties of the obtained encapsulated mineral fertilizers.

The encapsulated slow-acting mineral fertilizers were tested according to the European standard EN 
13266: 2001 [28]. For this purpose, $500 \mathrm{ml}$ of distilled water was poured into the beaker. $10 \mathrm{~g}$ of fertilizer weighed to the nearest $0.01 \mathrm{~g}$, was added to water, and the time was recorded. Then, the beaker was weighed with a magnetic stirrer, fertilizer, and water. The mass was recorded up to $1 \mathrm{~g}$. A magnetic stirrer was switched at a rate of about $300 \mathrm{rpm}$. The beaker was covered with a lid to prevent water from evaporating. The water temperature in the beaker was maintained at $25{ }^{\circ} \mathrm{C}$. To determine the content of the fertilizer in the solution, the liquid was poured carefully into another container not to transfer the undissolved fertilizer. Then the solution was analyzed by a conductometric method [29]. A fresh portion of distilled water at a temperature of $25{ }^{\circ} \mathrm{C}$ was poured into the beaker with the test fertilizer to obtain a previously fixed mass. Dissolving of the fertilizer was carried out until $75 \%$ of the components of the fertilizer were released from the capsule.

The vegetation experiment of the effect of fertilizers on the kinetics of plant growth was carried out in four parallel experiments. The fertilizer application rate was $1000 \mathrm{~kg} / \mathrm{ha}$. The fertilizers were applied once during the sowing of the crop. The soil was a dark grey podzolic silt-loamy loam.

To study the effect of encapsulated mineral fertilizers on the kinetics of the plant growth and development, we have reproduced the regimes of feeding and watering plants close to the conditions in greenhouse farms.

The experiment included 3 options:

1. Control (without fertilizers);

2. Nitromophos (N: P: K = 16:16:16), GF;

3. Fertilizer encapsulated with modified PET, $(\mathrm{EF})$.

Watercress salad was planted in pots of $1 \cdot 10^{-4} \mathrm{~m}^{3}$. The temperature during the growing season ranged from 13 to $19{ }^{\circ} \mathrm{C}$. During the growing season, care and observation of the plants (thinning, loosening of the soil, watering of $0.075-0.15 \mathrm{~kg} \mathrm{~m}^{3}$ ) were performed. The size of the terrestrial part of the plants, their development, and mass were noted (photographed) and compared regularly. Conclusions on the effectiveness of the application of encapsulated fertilizers were made according to the results of the study.

\section{Results and Discussion}

The test results of the nitroamophos encapsulated with modified polyethylene terephthalate-sorbent-lignin mixture are shown in Fig. 4. The obtained results show that the kinetic dissolution curves are predictable; the process proceeds smoothly without abrupt downturns or rises. This is the proof of a uniform, high-quality coating that enables the production of long-acting mineral fertilizers with the required release time.

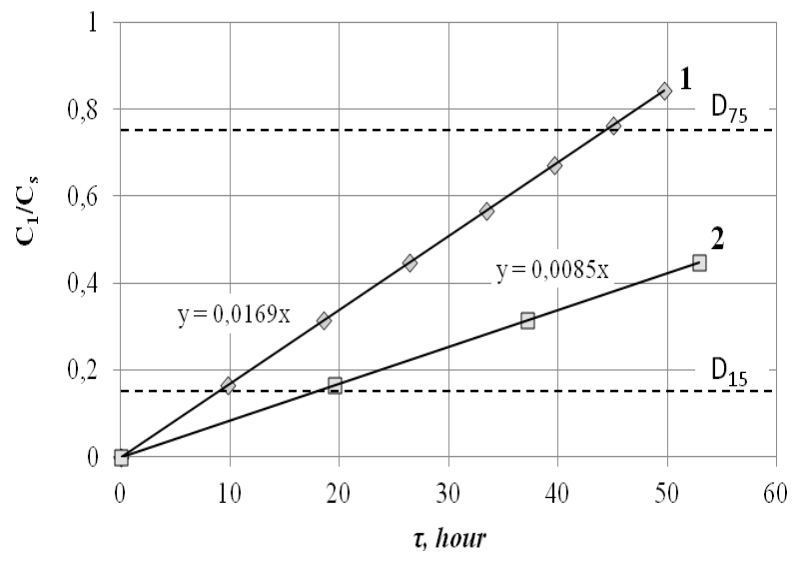

Fig. 4. Kinetic dependences of the release of nitroamophos from encapsulated particles coated with a shell based on modified PET of different thickness (\% wt): $1-10 ; 2-20$

Visualization of the growth kinetics of watercress salad fed with different types of fertilizers on the 30th and the 45th days of the observation is presented in Fig. 5. The graphs of the growth kinetics of watercress salad drawn according to the results of the observation are presented in Fig. 6.

The research data show that the fertilizer encapsulated with modified PET has performed better than conventional granular fertilizer. This can be explained by the fact that in the case of the granular fertilizer, much of it is washed away, causing a lack of nutrients in the substrate. And the encapsulated fertilizers, thanks to their prolongation ability, released the nutrients more slowly and allowed the plant to absorb them fully. The plants developed evenly throughout the growing season, and in the case of the granular fertilizer, we observed a jump in the plant growth and its elongation at the initial stage.

We have additionally conducted small-scale studies on the effectiveness of the use of mineral fertilizers encapsulated with modified PET using crops such as potatoes, soybeans, and maize [30]. The studies have shown that the efficiency of the use of encapsulated fertilizers compared to granular fertilizers is $30-50 \%$ higher with a lower consumption of mineral fertilizers. At the same time, environmental losses from the application of encapsulated fertilizers decrease by 40-70\% compared to granular fertilizers.

An important aspect is the ability to biodegrade capsule-forming material. According to [31], the modified PET in the shell during the growing season decomposes by $27-42 \%$. Modification of PET, as well as the content of hydrolysis lysine in the shell significantly accelerates the biodegradation process. All this indicates the viability and environmental safety of the use of modified PET to the composition for encapsulation of mineral fertilizers. 


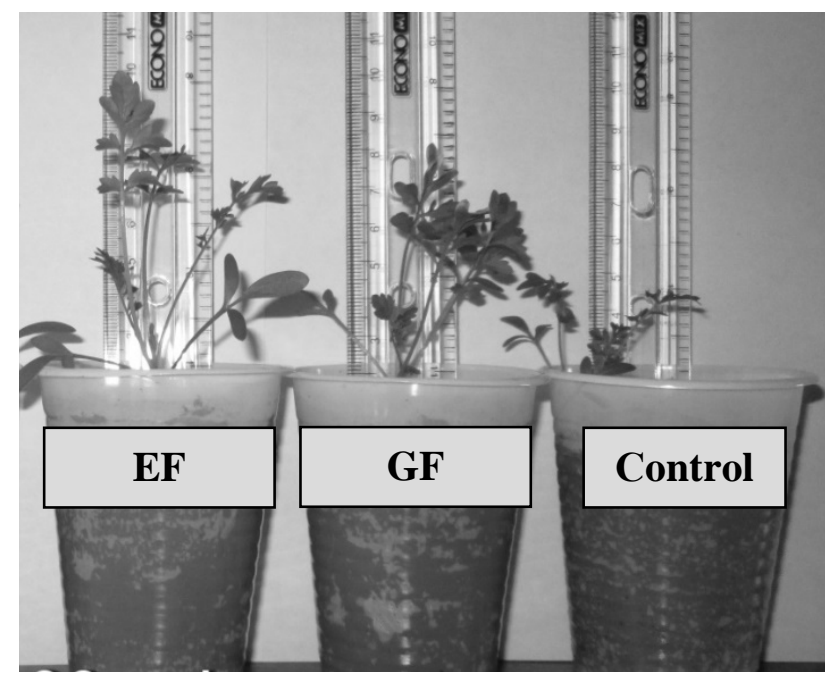

The $30^{\text {th }}$

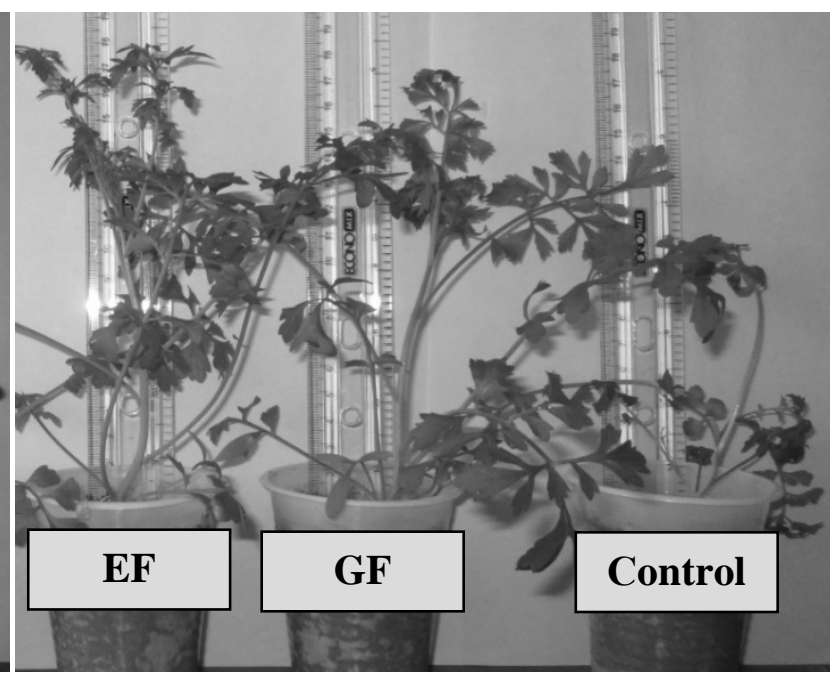

The $45^{\text {th }}$ day

Fig. 5. Visualization of the growth kinetics of watercress salad fed with various types of fertilizers

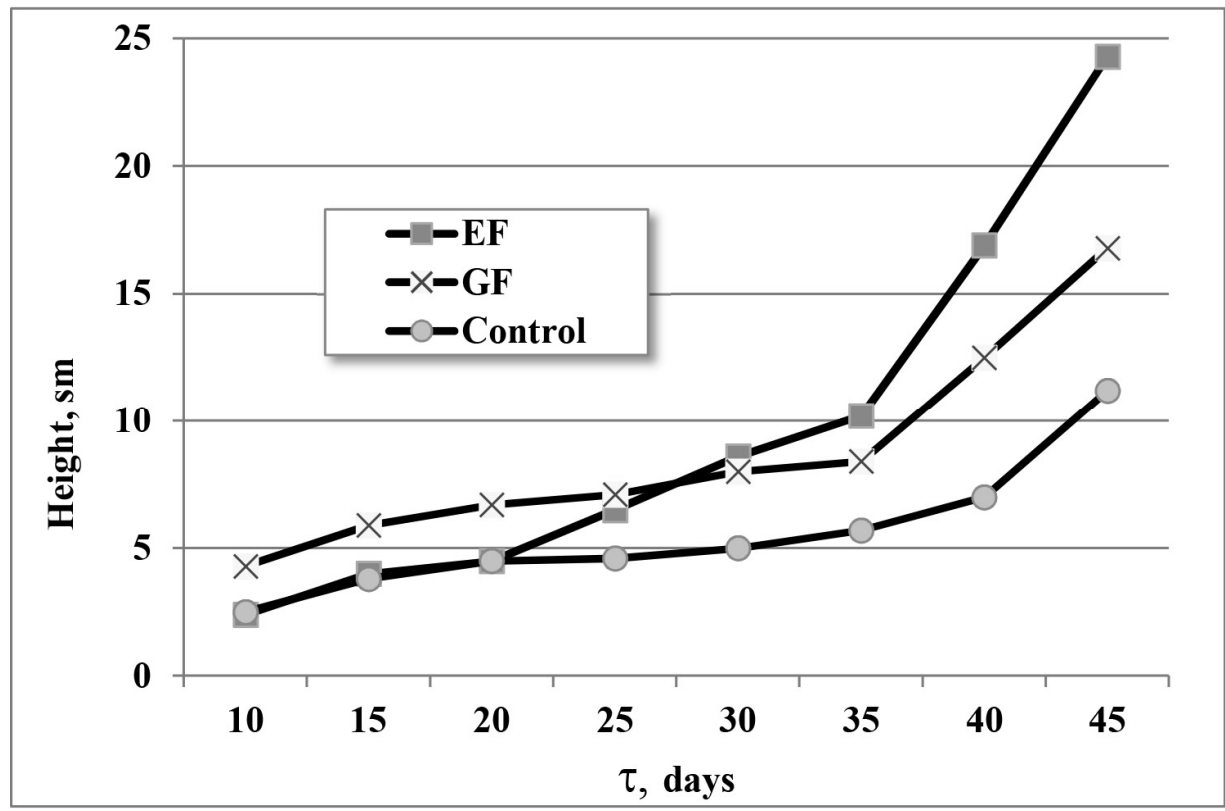

Fig. 6. Kinetics of the growth of watercress salad depending on the type of the applied fertilizer

\section{Conclusions}

The studies have shown that the encapsulated fertilizer is a promising form of mineral fertilizer that allows the sustainable release of the plant nutrients into the soil. This improves nutrition and prevents the loss of nutrients in the environment. This, in turn, contributes to the growth of the crop and the reduction of environmental hazards from environmental pollution.

It is established that modified PET can be a promising material for encapsulation. The technology of PET modification and capsule application to mineral fertilizer particles under fluidized bed conditions has been successfully tested in the laboratory.
The tests on the release of nutrients from mineral fertilizers encapsulated with modified PET confirmed the uniformity and quality of the coating, which makes it possible to get the long-acting mineral fertilizer with the required time of nutrients release.

The results of vegetation laboratory studies on the effect of fertilizers on the kinetics of the plant growth showed that in the case of encapsulated fertilizer application, the plant evenly developed throughout the growing season, and in the case of granular fertilizer application, we observed the jump in the plant growth and its elongation at the initial stage. 


\section{References}

[1] Baliuk S. and Lisovyi M.: Kontseptsiia ahrokhim. zabezpech. zemlerobstva Ukrainy na period do $2015 \mathrm{r}$. Miskdruk, Kharkiv 2009.

[2] Bulyhin S.: Agroecological j., 2015, 1, 36.

[3] Javorov V.M.: Ahrochimija. Pytannja, vidpovidi, testovi zavdan. FOP Sysyn O.V., Kamianets Podilskyi 2012.

[4] Jarchow M., Liebman M.: GCB Bioenergy, 2013, 5, 281. https://doi.org/10.1111/j.1757-1707.2012.01186.x

[5] Hrekov V., Datsko N., Poshediv N., Datsko M.: Okhorona rodiuchosti gruntiv, 2008, 4, 46.

[6] Miliutenko T., Demydov O., Sherstoboieva O.: Agroecological j., 2014, 1, 60

[7] Yahodyn B., Zhukov Yu., Kobzarenko V.: Ahrochimija. Kolos, Moskva 2002.

[8] Topolnyi F. P. et al.: Gruntoznavstvo z osnovamy heolohiï ta heohrafija gruntiv [vyd. 3-te vypr., i dopov.]. Kirovohrad 2014.

[9] Natkina N.: Fermerske hospodarstvo, 2010, 8, 15.

[10] Hospodarenko H.: Ahrokhimiia mineralnykh dobryv. Naukovyi svit, Kyiv 2003.

[11] Tomaszewskaa M., Jarosiewiczb A.: Desalination, 2006, 198 1-3, 346. https://doi.org/10.1016/j.desal. 2006.01.032

[12] http://www.gpa.unep.org/gpnm.html

[13] Chuchvaha I., Volkohon K.: Agroecological j., 2013, 2, 75

[14] Yashchenko L., Osetska A.: Visn. Kharkivskoho natsional. ahrarnoho univers. Ser. : Hruntoznavstvo, ahro-khimiia, zemlerobstvo, lisove hospodarstvo, 2013, 2, 100.

[15] Zaryshniak A., Lisovyi M.: Suchasni systemy udobrennia silskohospod. kultur u sivozminakh $\mathrm{z}$ riznoiu rotatsiieiu za osnovnymy gruntovo-klimatych. zonamy Ukrainy. Ahrarna nauka, Kyiv, 2008.

[16] Mokliachuk L., Zhukorskyi O. et al.: Agroecological j., 2012, 2, 36.

[17] Lopushniak V., Veha N.: Visn. ahrarnoi nauky Prychornomoria, 2015, 2, 2(1), 30.
[18] Fitieiev A., Semenov D., Miroshnychenko M. et al.: Visn. ahrarnoi nauky, 2013, 7, 16.

[19] Telehuz O., Kit M.: Ahroekolohichna otsinka gruntiv : monohraf. LNU im. I. Franka, Lviv 2013.

[20] Pyrohovskaia H., Kotovych Y., Kraevskyi A. et al.: Medlennodeistv. udobrenyia. Bel.NYYPA, Mynsk 2000.

[21] Kaminskyi V., Saiko V., Shevchenko I. et al.: Suchasni systemy zemlerobstva i tekhnoloh. vyroshchuvannia silskohospodars. kultur. "Edelveis", Kyiv 2012.

[22] Kraievskyi O., Osipov V., Kraievskyi O.: Visn. Sumskoho derzhav. Univers. Ser.: Ekonomika, 2013, 2, 20.

[23] Vashchuk V., Nahurskyi O.: Zbirnyk materialiv mizhnarod., nauk.-pr. konf. "1-y vseukr. zizd ekolohiv. Vinnytsia : "UNIVERSUM", Ukraine, Vinnytsia 2011, 135.

[24] Dietzel, R., M.E. Jarchow, M. Liebman: Crop Science, $2015,55,1$. https://doi.org/10.2135/cropsci2014.08.0572

[25] Vashchuk V., Nahurskyi O.: Visn. KrNU im. M. Ostrohradskoho 2010, 6 (65), 152.

[26] Moroz O., Malovanyi M., Synelnykov S., Nahurskyi O., Petrushka I., Tymchuk I.: Vseukr. nauk.-metod. konf. "Upravlinnia yakistiu pidhotovky fakhivtsiv", Ukraine, Odesa, 2019, 114.

[27] Hak V.: Rozrobka ta vlastyvosti plivkoutvoriuv. dlia fleksohrafskykh farb na osnovi vtorynnoho polietylentereftalatu. Dys. na zd. vch. st. kand. tekhn. nauk., NU "Lvivska politekhnika", Lviv, 2011.

[28] DSTU EN 13266:2017 Dobryva upovilnenoi dii. Vyznachennia dii pozhyvnykh rechovyn. Metod dlia pokrytykh dobryv (EN 13266:2001, IDT).

[29] Nagursky O., Malovanyy M., Sinelnikov S., Vashchuk V.: Sci. Bull. UNFU, 2015, 25(8), 139. https://doi.org/10.15421/40250823

[30] Nahurskyy O., Malovanyy M., Synelnikov S., Tymchuk I., Krylova G.: Environ. Probl., 2020, 5 (1), 35. https://doi.org/10.23939/ep2020.01.035

[31] Aamer Ali Shah, Hasan F., Hameed A., Ahmed S.: Biotechnol. Advances, 2008, 26 (3), 246. https://doi.org/10.1016/j.biotechadv.2007.12.005 